losofiske diskussion og den historiske revision betinger hinanden. Kritikken kan hente nyt skyts bag om Adorno og Heidegger ved at følge, hvordan de tidlige modernister tog deres livtag med markedet og teknikken, for der var en dobbelttydighed og nuancering, der er anvendelig i dag. Wallenstein inddrager også en nylæsning af arkitekturens samspil med medier og industri i efterkrigstidens USA, The Organizational Complex af Reinhold Martin fra 2004, som et bud på, hvad der er blevet af modernismen i denne transformation frem til i dag.

Vi kommer ikke uden om, at den stærke fremhævelse af tavsheden i kunsten virker som en undskyldning for, at teorien tager over og får sin rigelige taletid. Men bogen behandler fænomenet og får vist det produktive i tavshedens gestik og positurerne på linjen mellem kritik og affirmation. Når Mies proklamerede 'build, don't talk', så var det symptomatisk for den første generation af modernister, der havde snakket den nye holdning frem og nu bare skulle have næste generation til at handle efter den og bekræfte den. Men Mies var selv kortfattet og præcis både på skrift og i sine byggerier, så det er muligt at holde ham fast på ordene og blive ved med at spørge til, hvad det er for vilkår og muligheder for det moderne samfund, vi skal se i den glasarkitektur, der bliver ved med at hente inspiration fra ham.

\footnotetext{
Anders V. Munch er lektor $i$ designhistorie, Institut for Litteratur, Kultur og Medier, Syddansk Universitet.
}

\section{Call for artikler}

til KÆ̋K. Kultur og Klasse, nr. 110, 2010

TEMA: Overvågning i samtidskunsten: surveillance og sousveillance

Efter 9/11 er overvågning blevet intensiveret i mange lande, fx USA, England, Sverige og Danmark. Samtidskunsten har ladet sig udfordre af denne stigende overvågning, som man ser fx i Hasan M. Elahis netbaserede selvovervågningskunstværk Tracking Transience, i Camera Surveillance Players' avantgardistiske performance-opførelser i metroen af $\mathrm{fx}$ George Orwells 1984, i Mara Trallas humoristiske udsmykningshappenings og fx i Juli Zehs roman om sundhedsovervågning Corpus Delicti.

Med dette temanummer ønsker vi at åbne for en tværfaglig diskussion af, hvilken betydning overvågningen og dens opdukken i samtidskunsten har. Overvågning skal ikke forstås isoleret, men må analyseres i sammenhæng med den generelle udvikling i senmoderniteten. Overvågning rejser en diskussion af de 'koder', der styrer vores liv. Vi inviterer bidrag, der belyser temaet fra forskellige vinkler, fx litterære, visuelle, dramaturgiske, filmteoretiske, medievidenskabelige, kulturhistoriske, politiske, idehistoriske etc.

Deadline for abstracts: 1. februar 2010, omfang ca. 1000 ord

Send abstractet til Karen-Margrethe Simonsen, Institut for Æstetiske Fag, Aarhus Universitet: litkms@hum.au.dk. Se fuld beskrivelse af »call for artikler« på Aarhus Universitetsforlags hjemmeside: http://www.unipress.dk/ 